\title{
Arenibacter gen. nov., new genus of the family Flavobacteriaceae and description of a new species, Arenibacter latericius sp. nov.
}

\footnotetext{
1 Center of Marine Biotechnology, University of Maryland Biotechnology Institute, $701 \mathrm{E}$. Pratt St, Baltimore, MD 21202, USA

2 Pacific Institute of Bioorganic Chemistry of the Far-Eastern Branch of the Russian Academy of Sciences, Pr. 100 Let Vladivostoku 159, Russia

3 Seoul National University School of Biological Sciences, 56-1 Shillimdong, Kwanak-gu, Seoul 151-742, Korea

4 Institute of Microbiology of the Russian Academy of Sciences, 117811 Moscow, Russia

5 Institute of Marine Biology of the Far-Eastern Branch of the Russian Academy of Sciences, 690041, Vladivostok, Russia

${ }^{6}$ Department of Cell Biology and Molecular Genetics, University of Maryland, College Park, MD 20742, USA
}

\author{
Elena P. Ivanova, ${ }^{1,2}$ Olga I. Nedashkovskaya, ${ }^{2}$ Jongsik Chun, ${ }^{1,3}$ \\ Anatolii M. Lysenko, ${ }^{4}$ Galina M. Frolova, ${ }^{2}$ Vassilii I. Svetashev, ${ }^{5}$ \\ Mikhail V. Vysotskii, ${ }^{5}$ Valery V. Mikhailov, ${ }^{2}$ Anwarul Huq ${ }^{1,6}$ \\ and Rita R. Colwell ${ }^{1,6}$
}

Author for correspondence: Rita R. Colwell. Tel: +1 703292 8000. Fax: +1 7032929232. e-mail: rcolwell@nsf.gov

\begin{abstract}
Five dark-orange-pigmented, Gram-negative, rod-shaped, non-motile, aerobic bacterial strains were isolated from sandy sediment samples collected in the South China Sea in the Indian Ocean, from a holothurian, Apostichopus japonicus, in the Sea of Japan and from a brown alga, Chorda filum, from the Sea of Okhotsk in the Pacific Ocean. Phenotypic data were collected, demonstrating that the bacteria are chemo-organotrophic and require seawater-based media for growth. Polar lipids were analysed and $27 \%$ of the total extract comprised phosphatidylethanolamine as the major component. The predominant cellular fatty acids were branched-chain saturated and unsaturated [i-C15:0, i-C15:1, a-C15:0, C15:0, C16:1(n-7)]. The DNA base composition was 37.5-38.2 mol\% G+C. The level of DNA homology of the five isolates was $83-94 \%$, indicating that these isolates belong to the same species. A 165 rDNA sequence of the type strain KMM $426^{\top}$ was determined and phylogenetic analysis, based on neighbour-joining and Fitch-Margoliash methods, revealed that the type strain formed a distinct phyletic line in a clade corresponding to the family Flavobacteriaceae and represented a new genus. From the results of this polyphasic taxonomic analysis, it is proposed that the bacterial strains be classified in a new genus, Arenibacter gen. nov., and species, Arenibacter latericius sp. nov. The type strain is KMM 426 ${ }^{\top}$ (VKM B 2137D $^{\top}=$ LMG 19694 ${ }^{\top}=$ CIP $106861^{\top}$ ).
\end{abstract}

Keywords: Flavobacteriaceae, Arenibacter latericius

\section{INTRODUCTION}

A large number of representatives of the Cytophaga-Flavobacterium-Bacteroides group, rRNA superfamily V (Segers et al., 1993) or the 'Flavobacterium-Bacteroides' phylum (Gherna \& Woese, 1992) were described during the premolecular era in bacterial systematics. Based mainly on limited species definition and phenotypic similarities, the differentiation of species within this group was difficult. Recent genetic and phylogenetic advances,

The GenBank accession number for the $16 \mathrm{~S}$ rDNA sequence of Arenibacter latericius KMM $426^{\top}$ is AF052740. along with development and application of polyphasic taxonomy to flavobacteria systematics has changed the situation dramatically (Holmes, 1993; Vandamme et al., 1994; Bernardet et al., 1996; Nakagawa et al., 1997). Reclassification of misnamed species, emendation of the description for the family Flavobacteriaceae and genera within the family, and descriptions of the new species have led to the creation of novel taxa composed of bacteria from diverse environments (McGuire et al., 1987; Naganuma et al., 1993; Mudarris et al., 1994; Bernardet et al., 1996; Nakagawa \& Yamasato, 1996; Nakagawa et al., 1997; Bowman et al., 1997b, 1998, Gosink et al., 1998; Johansen et al., 1999).

We report here a polyphasic study (phenotypic, chemo- 
taxonomic, genetic and phylogenetic) of a new bacterial species isolated from different geographic areas: sandy sediments of the South China Sea, a holothurian from the Sea of Japan and a brown alga from the Sea of Okhotsk. On the basis of the results presented in this paper, we propose that the bacterial species be classified in a new genus, Arenibacter gen. nov., in the family Flavobacteriaceae, and describe the new species as Arenibacter latericius sp. nov.

\section{METHODS}

Bacterial cultures, sampling and isolation procedure. Sediment samples were collected from a depth of $20 \mathrm{~m}$ (salinity, $32 \%$; temperature, $18{ }^{\circ} \mathrm{C}$ ) in the South China Sea, near the island of $\mathrm{Ku}-\mathrm{Lao}-\mathrm{Re}$ (lat $15^{\circ} 21^{\prime} 08^{\prime \prime} \mathrm{N}$, long $109^{\circ} 07^{\prime} 02^{\prime \prime} \mathrm{E}$ ) during December 1988. The bacterial strain KMM 426 ${ }^{\mathrm{T}}$ was isolated from sandy sediment samples by plating $0.1 \mathrm{ml}$ of $1 \mathrm{~g}$ sediment suspended in $10 \mathrm{ml}$ natural sea water on medium B agar plates containing $0 \cdot 2 \%(\mathrm{w} / \mathrm{v})$ Bacto Peptone (Difco), $0 \cdot 2 \%(\mathrm{w} / \mathrm{v})$ casein hydrolysate (Merck), $0 \cdot 2 \%(\mathrm{w} / \mathrm{v})$ Bacto Yeast Extract (Difco), 0.1\% (w/v) glucose, 0.002\% (w/v) $\mathrm{KH}_{2} \mathrm{PO}_{4}, 0.005 \%$ (w/v) $\mathrm{MgSO}_{4} .7 \mathrm{H}_{2} \mathrm{O}$ and $1.5 \%$ (w/v) Bacto Agar (Difco) in $50 \%(\mathrm{v} / \mathrm{v})$ natural seawater and $50 \%(\mathrm{v} / \mathrm{v})$ distilled water at $\mathrm{pH} 7 \cdot 5-7 \cdot 8$, as described elsewhere (Ivanova et al., 1996). The holothurians, Apostichopus japonicus, were collected in November 1997 at a depth of $8 \mathrm{~m}$ (salinity, $33 \%$, temperature, $12^{\circ} \mathrm{C}$ ) at the Pacific Institute Bioorganic Chemistry Marine Experimental Station, Troitza Bay, Gulf of Peter the Great, Sea of Japan. The brown alga, Chorda filum, was collected in August 1997 at a depth of $10 \mathrm{~m}$ (salinity, $31 \%$, temperature, $12{ }^{\circ} \mathrm{C}$ ) near the island of Iturup, one of the Kuril Island chain, in the Sea of Okhotsk, Pacific Ocean. Isolates from invertebrates and algae were prepared aseptically as follows. The strains were isolated from tissue homogenates by plating $(0 \cdot 1 \mathrm{ml}$ of homogenate) on marine agar 2216 (Difco) agar plates and on medium B plates. After initial isolation, the strains were purified on medium $B$, maintained on the same semisolid medium $\mathrm{B}$ in tubes under mineral oil at $4{ }^{\circ} \mathrm{C}$ and stored at $-80{ }^{\circ} \mathrm{C}$ in marine broth (Difco) supplemented with $30 \%$ (v/v) glycerol.

All isolates were streaked on agar plates from broth culture every six months to ensure purity and viability.

Phenotypic analysis. Unless otherwise indicated, the phenotypic properties used for the characterization of Flavobacterium-related species were tested following established procedures (McMeekin et al., 1971; Smibert \& Krieg, 1994; Ivanova et al., 1996). To test for spreading growth and gliding motility, strains were grown on medium B with the peptone content reduced to $0 \cdot 2 \mathrm{~g}^{-1}$.

Gliding motility was verified by phase-contrast microscopy of hanging drop preparations. The bathochromic shift test with $20 \%(\mathrm{w} / \mathrm{v}) \mathrm{KOH}$ was performed to detect flexirubin pigmentation (Fautz \& Reichenbach, 1980).

Electron micrographs of negatively stained cells were prepared with a Zeiss EM $10 \mathrm{CA}$ electron microscope $(80 \mathrm{kV})$. A drop of particle-free (autoclaved and ultracentrifuged) distilled water was placed on the bacterial growth of a $24 \mathrm{~h}$ culture. A sample $(30 \mu \mathrm{l})$ of the resulting bacterial suspension was applied to carbon- and Formvar-coated 400-mesh copper grids, a drop of $1.25 \%$ uranyl acetate was added and the bacteria were allowed to adhere for $1 \mathrm{~min}$ at room temperature. Superfluous liquid was gently removed by using a piece of filter paper.

Substrate utilization tests. Starch, casein and gelatin hydrolysis was tested by the methods of Smibert \& Krieg (1994). Degradation of macromolecules by the strains was tested using medium B. Chitin $(1 \%, \mathrm{w} / \mathrm{v})$, elastin $(0 \cdot 1 \%$, $\mathrm{w} / \mathrm{v}$ ) and alginate (sodium salt; $0 \cdot 1 \%, \mathrm{w} / \mathrm{v}$ ) hydrolysis was determined by development of clear zones around the colonies. Cellulose hydrolysis was tested both by the cellulose overlay plate method ( $1 \%$ carboxymethylcellulose) and by examining strips of filter paper in liquid culture for dissolution (Smibert \& Krieg, 1994). The presence of $\alpha$ galactosidase and $\alpha$ - $N$-acetylgalactosaminidase was determined as described elsewhere (Bakunina et al., 1996). Briefly, glycosidase activities were tested with the $p$-nitrophenyl derivatives of relevant monosaccharides (Sigma): $p$ nitrophenyl- $\alpha$-D-galactopyranoside and $p$-nitrophenyl- $\alpha$ NAc-D-galactosaminide. Glycosidase activities of bacterial (cell-free) extracts were measured in $0 \cdot 1 \mathrm{M}$ phosphate buffer, $\mathrm{pH} 7.0$ at $20^{\circ} \mathrm{C}$. The reaction mixture consisted of $0.05 \mathrm{ml}$ bacterial extract and $0.05 \mathrm{ml}$ of the corresponding $p$ nitrophenyl glycoside $\left(1 \mathrm{mg} \mathrm{ml}^{-1}\right.$ in $50 \mathrm{mM}$ Tris/phosphate buffer, $\mathrm{pH} 7 \cdot 5$ ). The reaction was stopped by adding $0.1 \mathrm{ml}$ $1 \mathrm{M} \mathrm{Na}_{2} \mathrm{CO}_{3}$. One unit of enzyme activity was defined as the amount of enzyme that liberated $1 \mathrm{nmol} p$-nitrophenol $\mathrm{h}^{-1}$. Oxidative utilization of 95 carbon sources was tested using BIOLOG GN Microplates (Ruger \& Krambeck, 1994; Ivanova et al., 1998).

Growth at different temperatures, $\mathrm{NaCl}$ concentrations or $\mathrm{pH}$ was measured using $\mathrm{OD}_{660}$ after incubation for $24 \mathrm{~h}$ in medium B. Incubation temperatures employed ranged from 4 to $42{ }^{\circ} \mathrm{C}$. $\mathrm{NaCl}$ concentrations used were 0 to $15 \%$. The $\mathrm{pH}$ was adjusted, using $\mathrm{HCl}$ and $\mathrm{NaOH}$, in the range 4.5 to 12.0. Cultures were incubated on a rotary shaker at 160 r.p.m. for $24-36 \mathrm{~h}$ at $28^{\circ} \mathrm{C}$.

Antibiotic susceptibility. Susceptibility to antibiotics was tested by the diffusion plate method, employing medium B agar and disks impregnated with the following antibiotics $(\mu \mathrm{g})$ : kanamycin, 10; ampicillin, 10; benzylpenicillin, 10; streptomycin, 10; erythromycin, 15; gentamicin, 10; oxacillin, 20; lincomycin, 15; ristomycin, 25; rifampicin, 25; neomycin, 25; cephaloridin, 10; and polymyxin B, 25 .

Characterization of pigment. The strains were grown on medium B for $2 \mathrm{~d}$ at $28^{\circ} \mathrm{C}$. Pigments were extracted using methanol. Absorption spectra were determined between 250 and $700 \mathrm{~nm}$ (spectrophotometer, Specord M40).

Polar lipids. Polar lipids were extracted from wet cells, using the Bligh \& Dyer (1953) method. Column chromatography was carried out using silica gel L 100/160 (Lachema) and DEAE cellulose (Reanal). Polar lipids were subjected to two-dimensional TLC on silica gel (KSK) thin layer plates $(10 \times 10 \mathrm{~cm})$.

Following treatment with solvents [chloroform/methanol/ ammonium hydrate/benzene $(65: 30: 6: 10$, by vol.) (first dimension) and chloroform/methanol/acetone/acetic acid/ benzol/water $(70: 30: 5: 4: 1: 10$, by vol.) (second dimension)], compounds were detected on chromatograms by spraying with non-specific reagents $(50 \%$ sulfuric acid in methanol by heating at $180{ }^{\circ} \mathrm{C}$ ) and with specific reagents (ninhydrin, Dragendorff and periodate-Schiff). Quantification of phospholipids on two-dimensional chromatograms was performed by the method of Vaskovsky et al. (1975). 
Fatty acids methyl ester (FAME) analysis. The analysis of FAMEs was performed by GLC $(30 \mathrm{~m} \times 0.25 \mathrm{~mm}$ Supelcowax 10 column, $210^{\circ} \mathrm{C}$ ) as described by Svetashev et al. (1995).

DNA base composition. DNA was isolated following the method of Marmur (1961) and the $G+C$ content of the DNA was determined by the thermal denaturation method of Marmur \& Doty (1962). DNA-DNA hybridization was performed spectrophotometrically and initial renaturation rates were recorded as described by De Ley et al. (1970).

Phylogenetic analysis. PCR, cloning and sequencing of $16 \mathrm{~S}$ rDNA were carried out using the Taq DyeDeoxy Terminator Cycle Sequencing Kit (Applied Biosystems) and an Applied Biosystems 373A DNA sequencer, as described previously by Chun \& Goodfellow (1995). The resultant 16S rDNA sequence was aligned manually against sequences obtained from the GenBank database. Phylogenetic trees were constructed using the Fitch-Margoliash (Fitch \& Margoliash, 1967), neighbour-joining (Saitou \& Nei, 1987) and maximum-parsimony (Fitch, 1972) methods. Evolutionary distance matrices were calculated according to Jukes \& Cantor (1969). The PHYLIP package (Felsenstein, 1993) was used for all analyses. The resultant unrooted tree topology was evaluated by bootstrap analyses (Felsenstein, 1985) of the neighbour-joining tree based on 1000 resamplings.

\section{RESULTS}

\section{Phenotypic characteristics of the isolates}

The bacteria isolated in this study were Gram-negative, strictly aerobic, non-motile and non-gliding rods with parallel or slightly irregular sides, $0.4-0.6 \mu \mathrm{m}$ in diameter and 3-5 $\mu \mathrm{m}$ long (Fig. 1). On marine agar and $B$ medium, colonies were uniformly round, $2-3 \mathrm{~mm}$ in diameter, convex, translucent and yellow to reddishorange. The bacteria did not form endospores, nor did they accumulate poly- $\beta$-hydroxybutyrate as an intracellular reserve product, and they did not possess an arginine dihydrolase system. They were oxidase-,

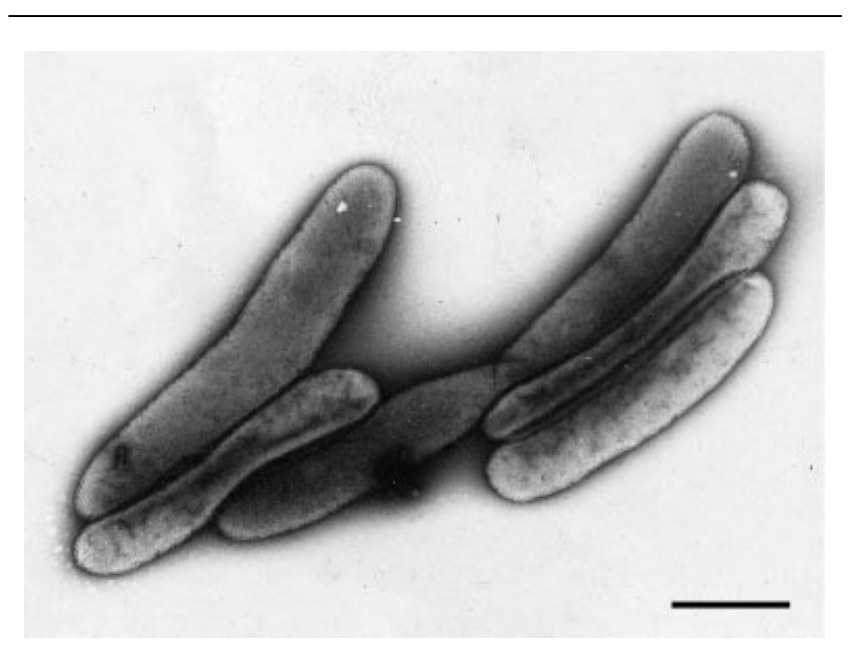

Fig. 1. Electron micrograph of a negatively stained cell of Arenibacter latericius KMM 426 ${ }^{\top}$. Bar, $1 \mu \mathrm{m}$. catalase- and alkaline phosphatase-positive, and required $\mathrm{Na}^{+}$for growth. Growth occurred in media containing $1-7 \% \mathrm{NaCl}$. The temperature range for growth was $10-37^{\circ} \mathrm{C}$, with optimum growth occurring at $28{ }^{\circ} \mathrm{C}$. No growth was detected at 4 or $42^{\circ} \mathrm{C}$. The $\mathrm{pH}$ range for growth was $6 \cdot 0-10 \cdot 0$, with optimum growth occurring between $\mathrm{pH} 7 \cdot 5$ and $8 \cdot 5$.

Agar, chitin, starch, alginate, gelatin, cellulose, Tween$20,-40,-60$, and -80 , and DNA were not hydrolysed. $\alpha-$ $N$-Acetylgalactosaminidase was produced. $\alpha$-Galactosidase was produced by only one strain, KMM $426^{\mathrm{T}}$; elastin was hydrolysed by two strains (Table 1). $\alpha$-D-Glucose, L-glutamic acid, L-ornithine, uridine, glycerol, DL- $\alpha$-glycerol phosphate, glucose 1phosphate and glucose 6-phosphate were utilized according to BIOLOG results. Dextrin, $N$-acetylD-galactosamine, $N$-acetyl-D-glucosamine, cellobiose, D-fructose, $\alpha$-lactose, $\alpha$-D-lactose lactulose, glycogen, maltose, D-mannitol, D-mannose, D-mellibiose, $\beta$ methyl-D-glucoside, D-raffinose, sucrose, D-trehalose, DL-lactic acid, turanose, succinamic acid, glucuronamide, alaninamide, L-alanine, L-alanylglycine, L-asparagine, L-aspartic acid, glycyl-L-aspartic acid, glycyl-L-glutamic acid, L-proline, D-serine, L-serine and L-threonine were weakly utilized. None of the bacterial species in the GN Microplate database (BIOLOG) matched the utilization pattern of KMM $426^{\mathrm{T}}$.

All strains were susceptible to erythromycin, ampicillin, lincomycin, ristomycin, rifampicin, cephaloridin, oleandomycin and polymyxin B. (Table 1).

The bacteria produced carotenoid pigments with wavelength absorbance spectral peaks at 338, 408, 434, 459 and $488 \mathrm{~nm}$. The bathochromic shift test with $20 \% \mathrm{KOH}$ revealed no flexirubin pigments. The polar lipids $\mathrm{A}$ in the lipid extract of strain KMM $426^{\mathrm{T}}$ accounted for $27 \%$ of the polar lipids, but about $50 \%$ of those were phospholipids. The overall polar lipid pattern included phosphatidylethanolamine as the major compound and two unidentified polar lipids reacting with ninhydrin, but negative for phosphoruscontaining compounds.

\section{Fatty acid composition}

The most relevant cellular fatty acids were branchedchain saturated and unsaturated, namely i15:0, i15:1, a15:0, 15:0 and 16:1(n-7) (Table 2). In addition, about $11.34 \%$ of fatty acids could not be identified.

\section{DNA base composition and DNA relatedness}

The $\mathrm{G}+\mathrm{C}$ content of the DNA ranged from 37.5 to $38.2 \mathrm{~mol} \%$ (determined by the thermal denaturation method). The levels of DNA relatedness of the strains isolated from sandy sediment, a holothurian and an alga are presented in Table 3. Since the level of DNA homology of five of the strains was $83-94 \%$, all five 
Table 1. Major phenotypic characteristics of Arenibacter latericius

\begin{tabular}{|c|c|c|}
\hline \multirow[t]{2}{*}{ Characteristic } & \multicolumn{2}{|c|}{ Arenibacter latericius } \\
\hline & KMМ 426 & $n=4^{*}$ \\
\hline Flagellation & - & 0 \\
\hline Gliding motility & - & 0 \\
\hline Oxidase, catalase activity & + & 100 \\
\hline $\mathrm{Na}^{+}$required for growth & + & 100 \\
\hline Requirement for organic growth factors & - & 0 \\
\hline Arginine dihydrolase activity & - & 0 \\
\hline Denitrification & + & 100 \\
\hline Indole production & - & 0 \\
\hline Urease & + & 100 \\
\hline Phenylalanine deaminase & - & 0 \\
\hline Haemolytic activity & + & 100 \\
\hline \multicolumn{3}{|l|}{ Degradation of: } \\
\hline Agar, alginic acids, starch, gelatin, cellulose, chitin, Tween-20, $-40,-60,-80$, DNA & - & 0 \\
\hline Elastin & - & 50 \\
\hline \multicolumn{3}{|l|}{ Production of: } \\
\hline$\alpha$-Galactosidase & + & 0 \\
\hline$\alpha$ - $N$-Acetylgalactosaminidase, alkaline phosphatase & + & 100 \\
\hline \multicolumn{3}{|l|}{ Growth at: } \\
\hline $10-37^{\circ} \mathrm{C}$ & + & 100 \\
\hline $1-7 \% \mathrm{NaCl}$ & + & 100 \\
\hline \multicolumn{3}{|l|}{ Utilization of: } \\
\hline Melibiose, citrate, trehalose & - & 0 \\
\hline Lactose & + & 100 \\
\hline Glycerol & + & 75 \\
\hline L-Arginine, L-tyrosine & + & 100 \\
\hline \multicolumn{3}{|l|}{ Susceptability to: } \\
\hline Kanamycin $(30 \mu \mathrm{g})$ & - & 0 \\
\hline Ampicillin $(10 \mu \mathrm{g})$ & + & 100 \\
\hline Benzylpenicillin $(10 \mu \mathrm{g})$ & - & 0 \\
\hline Streptomycin $(10 \mu \mathrm{g})$ & - & 0 \\
\hline Erythromycin $(15 \mu \mathrm{g})$ & + & 100 \\
\hline Gentamicin $(10 \mu \mathrm{g})$ & - & 0 \\
\hline Oxacillin $(20 \mu \mathrm{g})$ & - & 0 \\
\hline Lincomycin $(15 \mu \mathrm{g})$ & + & 100 \\
\hline Ristomycin $(25 \mu \mathrm{g})$ & + & 100 \\
\hline Rifampicin $(25 \mu \mathrm{g})$ & + & 100 \\
\hline Neomycin $(25 \mu \mathrm{g})$ & - & 0 \\
\hline Cephaloridin $(10 \mu \mathrm{g})$ & + & 100 \\
\hline Polymyxin B $(25 \mu \mathrm{g})$ & - & 0 \\
\hline
\end{tabular}

* Values are the percentages of the four strains tested that are positive.

strains were assigned to a single species genotypically (Wayne et al., 1987).

\section{Phylogeny}

An almost complete 16S rDNA sequence (1444 nt) was obtained for strain KMM 426 ${ }^{\mathrm{T}}$. Phylogenetic analyses revealed that the organism is an authentic member of the Cytophaga-Flavobacterium-Bacteroides phylum (Fig. 2). Zobellia (formerly Cytophaga) uliginosa formed a monophyletic clade with strain KMM $426^{\mathrm{T}}$ at a low nucleotide sequence similarity $(91 \cdot 4 \%)$. The relationship was confirmed in all three tree-making analyses and by the high bootstrap value ( $97 \%$ ), based on the neighbour-joining algorithm. The next closest neighbour was Cellulophaga lytica (Johansen et al., 1999), sharing $90 \cdot 2 \% 16$ S rDNA sequence similarity. Phylogenetic affiliation of Cellulophaga lytica to a monophyletic clade encompassing strain KMM $426^{\mathrm{T}}$ and Cytophaga uliginosa was unclear, as the relationship was not supported by a significant bootstrap value $(51 \%)$ and was not observed in the maximumparsimony analysis (results not shown). 
Table 2. Cellular fatty acid composition of Arenibacter latericius $\mathrm{KMM} 426^{\top}$

\begin{tabular}{|c|c|}
\hline Fatty acid & $\begin{array}{c}\text { Arenibacter latericius } \\
\text { KMM } 426^{\mathrm{T}}\end{array}$ \\
\hline \multicolumn{2}{|c|}{ Saturated acids } \\
\hline $13: 0$ & $0 \cdot 07$ \\
\hline $14: 0$ & $1 \cdot 03$ \\
\hline $15: 0$ & $13 \cdot 26$ \\
\hline $16: 0$ & $3 \cdot 30$ \\
\hline $17: 0$ & $0 \cdot 18$ \\
\hline $18: 0$ & $0 \cdot 10$ \\
\hline Total & $17 \cdot 96$ \\
\hline \multicolumn{2}{|c|}{ Branched chain acids } \\
\hline $\mathrm{i} 13: 0$ & $0 \cdot 30$ \\
\hline a13:0 & $0 \cdot 13$ \\
\hline i14:0 & $0 \cdot 17$ \\
\hline a14:0 & $0 \cdot 17$ \\
\hline i15:0 & $17 \cdot 26$ \\
\hline a15:0 & $6 \cdot 60$ \\
\hline i16:0 & $0 \cdot 92$ \\
\hline a16:0 & $0 \cdot 13$ \\
\hline i17:0 & $0 \cdot 75$ \\
\hline a17:0 & $0 \cdot 28$ \\
\hline Total & $26 \cdot 71$ \\
\hline \multicolumn{2}{|c|}{ Unsaturated acids } \\
\hline $14: 1$ & $0 \cdot 15$ \\
\hline $15: 1(n-8)$ & $0 \cdot 76$ \\
\hline $15: 1(n-6)$ & $2 \cdot 33$ \\
\hline $16: 1(n-7)$ & $10 \cdot 96$ \\
\hline $16: 1(n-5)$ & $0 \cdot 34$ \\
\hline $17: 1(n-8)$ & $0 \cdot 57$ \\
\hline $17: 1(n-6)$ & $1 \cdot 23$ \\
\hline Total & $16 \cdot 34$ \\
\hline \multicolumn{2}{|c|}{$\begin{array}{l}\text { Branched chain } \\
\text { unsaturated acids }\end{array}$} \\
\hline i15: 1 & $19 \cdot 27$ \\
\hline a15:1 & $1 \cdot 73$ \\
\hline i16: 1 & $0 \cdot 32$ \\
\hline a16:1 & - \\
\hline i17: 1 & $5 \cdot 79$ \\
\hline a17: 1 & $0 \cdot 56$ \\
\hline Total & $27 \cdot 67$ \\
\hline Sum & $88 \cdot 66$ \\
\hline
\end{tabular}

\section{DISCUSSION}

The flavobacteria-like organisms isolated from sandy sediment samples collected in the South China Sea, near the island of $\mathrm{Ku}-\mathrm{Lao}-\mathrm{Re}$, from a holothurian, Apostichopus japonicus, and from a brown alga, Chorda filum, were subjected to a polyphasic taxonomy analysis. The bacteria were aerobic, non-motile, Gram-negative, non-spore-forming rods without resting stages. The $\mathrm{G}+\mathrm{C}$ content of the DNA ranged from 37.5 to $38.2 \mathrm{~mol} \%$. All strains studied produced oxidase, catalase and phosphatase, were not proteolytic and did not hydrolyse starch, agar, gelatin or cellulose. The strains synthesized carotenoid pigments, but not flexirubin, as the basis for the colour of the colonies. The presence of branched-chain saturated and unsaturated fatty acids, namely i15:0, i15:1, a15: $0,15: 0$ and $16: 1(n-7)$, and the absence of hydroxy fatty acids were characteristic for the bacteria. In spite of the intraspecific heterogeneity of the fatty acid content of the micro-organisms belonging to rRNA superfamily $\mathrm{V}$, the high levels of i15:0 and i17:0 $3 \mathrm{OH}$ are diagnostic features (Holmes et al., 1984; Holmes 1993; Bernardet et al., 1996). In contrast to other Flavobacterium-related bacteria, the bacteria included in this study were distinct by the lack of hydroxy fatty acids.

Taken together, all of the features lead to the conclusion that these strains bear sufficient resemblance to species and genera included in the emended family Flavobacteriaceae (Bernardet et al., 1996). Though there are problems concerning the definition of the families Flavobacteriaceae and Cytophagaceae, the strains described in this study can easily be differentiated from representatives of the family $\mathrm{Cyto}$ phagaceae Stanier 1940, which includes the genera Cytophaga [emended genus restricted to Cytophaga hutchinsonii and Cytophaga aurantiaca (Nakagawa \& Yamasato, 1996), Flexithrix and Sporocytophaga] by lack of gliding motility and lack of ability to decompose agar and cellulose. These features, together with the lack of ability to hydrolyse starch, make it relatively easy to differentiate new strains from Zobellia (Cytophaga) uliginosa and Cellulophaga lytica, the closest phylogenetic neighbours (Table 4). The genera Capnocytophaga, Ornithobacterium and Riemerella, members of the Flavobacteriaceae, differ from the bacteria studied by their capnophilic metabolism. Bacteria of the genera Bergeyella, Ornithobacterium, Riemerella and Weeksella (Botha et al., 1989) represent solitary rRNA branches that are nonpigmented, while Arenibacter latericius is pigmented. The genera Empedobacter and Chryseobacterium also belong to separate rRNA branches, distinct by several phenotypic properties and a low DNA $\mathrm{G}+\mathrm{C}$ content (Table 4).

Placement of the isolates studied in the genus Flavobacterium, specifically KMM $426^{\mathrm{T}}$, is not appropriate because of the lack of ability to decompose gelatin, casein and Tween compounds. One of the two new Flavobacterium-like taxa, described recently for marine bacteria (Bowman et al., 1997a) and related to the Flexibacter maritimus rRNA branch, namely Psychroserpens burtonensis, has a characteristic cell morphology, non-saccharolytic metabolism and low DNA $\mathrm{G}+\mathrm{C}$ content. Strains of the second taxon, Gelidibacter algens, exhibited gliding motility and significant

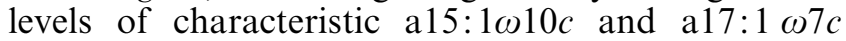
lipids. To establish the precise phylogenetic affiliation 
Table 3. DNA relatedness among tested strains of Arenibacter latericius

\begin{tabular}{|lcc|}
\hline Strain & $\begin{array}{c}\text { G+C content } \\
(\mathbf{m o l} \%)\end{array}$ & $\begin{array}{c}\text { Percentage hybridization with DNA from } \\
\text { A. } \text { latericius KMM 426 }^{\mathbf{T}}\end{array}$ \\
\hline KMM 426 & $37 \cdot 5$ & 100 \\
KMM 3522 & $38 \cdot 0$ & 83 \\
KMM 3557 & $37 \cdot 9$ & 94 \\
KMM 3523 & $38 \cdot 2$ & 84 \\
KMM 3527 & $37 \cdot 9$ & 94 \\
KMM 3528 & $37 \cdot 7$ & 83 \\
\hline
\end{tabular}

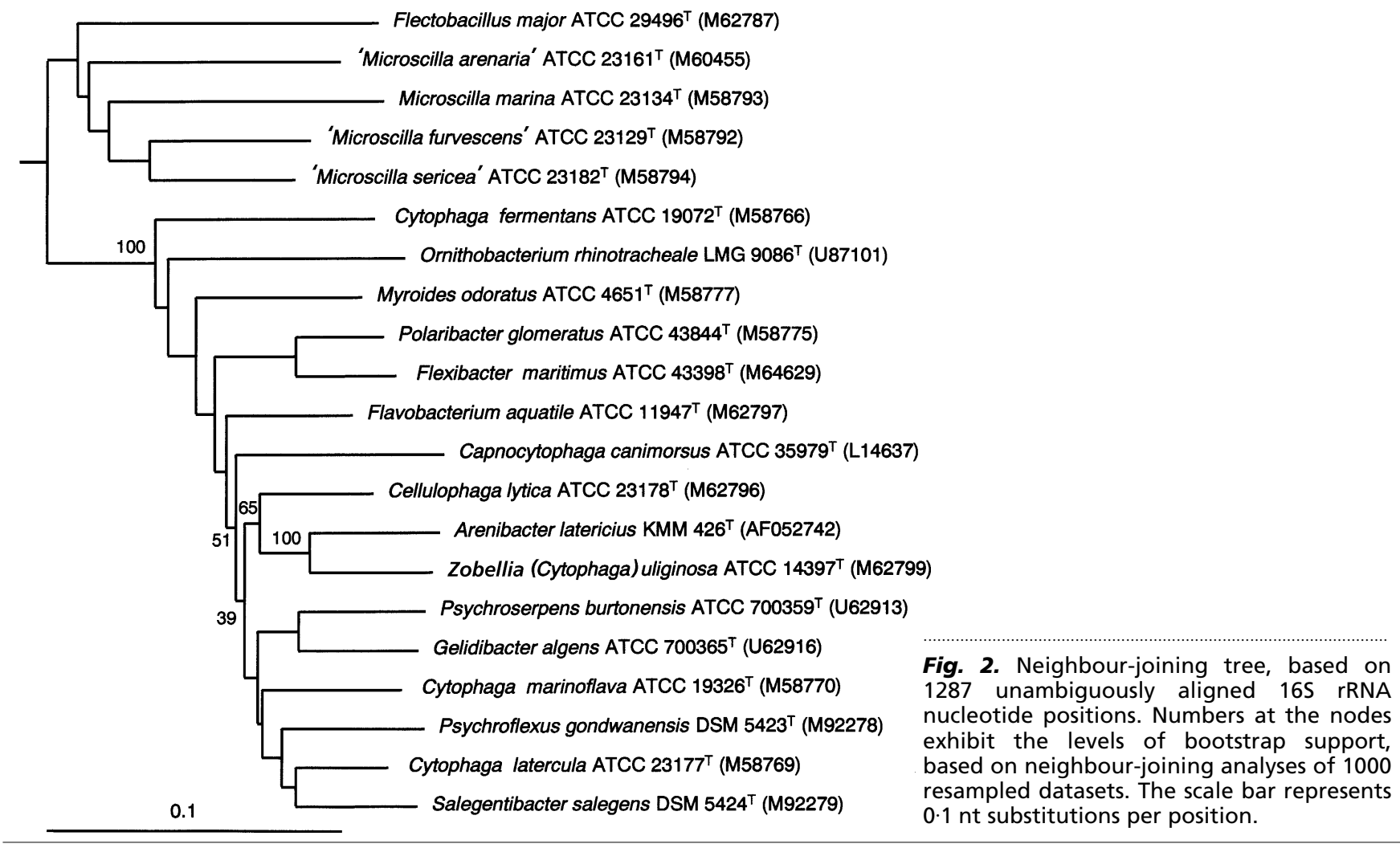

of strain KMM $426^{\mathrm{T}}$, almost the entire 16S rDNA gene sequence was determined. A phylogenetic analysis was done, including all of the taxa from rRNA superfamily V. As defined by Gherna \& Woese (1992), the phylum Cytophaga-Flavobacterium-Bacteroides is composed of five major phylogenetic subgroups: Cytophaga, Flavobacterium, Sphingobacterium, Saprospira and Bacteroides. Our analysis showed that strain KMM $426^{\mathrm{T}}$ formed a related but distinct lineage within the Cytophaga-Flavobacterium-Bacteroides phylum and its $16 \mathrm{~S}$ rDNA sequence was most similar to Zobellia (Cytophaga) uliginosa. The level of $16 \mathrm{~S}$ rDNA sequence similarity with other members of the phylum was $91.4 \%$ and clearly indicates that the bacteria isolated in this study represent a novel genus. Bootstrap resampling showed this lineage to be statistically reliable.
Taking into consideration all the data presented, the environmental isolates could not be placed in any of the species or genera currently included in the family Flavobacteriaceae. Consequently, we propose that strain KMM $426^{\mathrm{T}}$ be placed in a new genus, Arenibacter gen. nov., as Arenibacter latericius sp. nov.

\section{Description of Arenibacter gen. nov.}

Arenibacter (A.re.ni.bac'ter. L. fem. n. arena sand; N.L. masc. n. bacter rod; N.L. masc. n. Arenibacter sand-dwelling rod).

Rod-shaped cells with pearled or slightly irregular sides and rounded ends, about $3-5 \mu \mathrm{m}$ long and $0.4-0.6 \mu \mathrm{m}$ diameter. Non-motile. Does not exhibit gliding motility. Gram-negative. Does not form endospores or resting stages. Does not accumulate 
Table 4. Differential characteristics of Arenibacter latericius of the family Flavobacteriaceae and other allied marine genera

ND, Not determined; A, strict aerobes; F, facultative anaerobes; M, microaerophiles; - , negative; +, positive; v, variable; \pm , previously reported results differ; Cad, cadaverine; Spd, spermidine; Hspd, homospermidine. Data from Bernardet et al. (1996), Nakagawa et al. (1997), Bowman et al. (1997), Mudarris et al. (1994), Botha et al. (1989), McGuire et al. (1987) and this study.

\begin{tabular}{|c|c|c|c|c|c|c|c|c|c|c|c|c|}
\hline Taxon/species & Habitat & $\begin{array}{l}\text { Reaction to } \\
\text { oxygen }\end{array}$ & $\begin{array}{l}\text { Pigmentation/ } \\
\text { flexirubin }\end{array}$ & $\begin{array}{l}\text { Gliding } \\
\text { motility }\end{array}$ & $\begin{array}{l}\text { Seawater } \\
\text { requirement }\end{array}$ & $\begin{array}{l}\text { Amino acid } \\
\text { requirement }\end{array}$ & $\begin{array}{l}\text { Carbohydrate } \\
\text { utilization }\end{array}$ & Starch & Sphingolipid & Polyamine & Quinone & $\begin{array}{c}\text { GC content } \\
(\mathrm{mol} \%)\end{array}$ \\
\hline Arenibacter latericius & Marine & A & $+1-$ & - & + & - & + & - & - & $\mathrm{ND}$ & ND & $38-39$ \\
\hline Bergeyella & Parasitic saprophytic & A & $-1-$ & - & - & - & - & $\mathrm{v}$ & - & ND & MK-6 & $35-37$ \\
\hline Capnocytophaga & Parasitic saprophytic & $\mathrm{F}$ & $+1-$ & + & - & + & + & ND & MK-6 & $33-41$ & & \\
\hline Chryseobacterium & Free-living, parasitic & A & $+1+$ & $\mathrm{v}$ & - & - & + & - & - & Hspd & MK-6 & $33-38$ \\
\hline Cellulophaga lytica & Free-living & A & $+1-$ & + & $\mathrm{v}$ & - & + & + & ND & ND & ND & $31 \cdot 0$ \\
\hline Cytophaga hutchinsonii & Free-living, soil & A & $+1-$ & + & $\mathrm{v}$ & - & $\mathrm{v}$ & + & ND & Hspd & MK-7 & $39-42$ \\
\hline [Cytophaga] marinoflava & Marine & A & $+1-$ & + & - & - & + & + & $\mathrm{ND}$ & ND & ND & $33 \cdot 0$ \\
\hline Zobellia (Cytophaga) uliginosa & Free-living & A & $+/ \pm$ & + & + & - & + & + & ND & ND & ND & $32 \cdot 0$ \\
\hline Empedobacter & Free-living, parasitic & A & $+1-$ & - & - & - & - & - & - & Hspd & MK-6 & $31-33$ \\
\hline Flammeovirga & Marine & A & $+1-$ & + & + & - & + & + & ND & $\mathrm{Cad}$ & MK-6 & $35-37$ \\
\hline Flavobacterium & Free-living, saprophytic & A & $+/ \mathrm{v}$ & $\mathrm{v}$ & $\mathrm{v}$ & - & + & + & - & Hspd & MK-6 & $32-37$ \\
\hline Psychroflexus gondwanensis & Hypersaline lake & A & $+1-$ & ND & - & ND & + & + & ND & ND & ND & ND \\
\hline Salegentibacter salegens & Hypersaline lake & A & $+1-$ & ND & - & ND & + & + & ND & ND & ND & ND \\
\hline Flectobacillus & Marine & A & $+1-$ & - & + & - & - & $\mathrm{v}$ & ND & $\mathrm{ND}$ & ND & $34-40$ \\
\hline Flexibacter flexilis & Fresh water & A & $+1-$ & + & - & - & - & ND & Hspd & MK-7 & $29-48$ & \\
\hline Flexibacter maritimus & Parasitic, saprophytic & A & $+1-$ & + & + & + & - & - & ND & ND & ND & $31 \cdot 0$ \\
\hline Gelidibacter & Marine & A & $+1-$ & + & + & + & - & + & ND & ND & ND & $36-38$ \\
\hline Marinilabilia & Marine & $\mathrm{F}$ & $+1-$ & - & + & $\mathrm{ND}$ & Spd & MK-7 & $37-41$ & & & \\
\hline Microscilla & Marine & A & $+1-$ & $\mathrm{v}$ & + & - & + & + & ND & ND & $\mathrm{ND}$ & $32-44$ \\
\hline Ornithobacterium & Parasitic & $\mathrm{F}$ & $-1-$ & - & - & ND & $\mathrm{N}$ & MK-6 & $37-39$ & & & \\
\hline Persicobacter & Marine & A & $+1-$ & + & + & - & + & + & ND & Spd & MK-7 & $40-42$ \\
\hline Psychroserpens & Marine & A & $+1-$ & - & + & + & - & - & ND & ND & ND & $27-29$ \\
\hline Riemerella & Parasitic & M & $-1-$ & - & - & + & $\mathrm{ND}$ & ND & MK-6 & $29-35$ & & \\
\hline Sphingobacterium & Free-living & A & $+1-$ & + & - & + & + & ND & + & Hspd & MK-7 & $39-45$ \\
\hline Weeksella & Parasitic, saprophytic & A & $-1-$ & - & - & - & - & $\mathrm{v}$ & - & ND & MK-6 & $35-38$ \\
\hline
\end{tabular}


poly- $\beta$-hydroxybutyrate as an intracellular reserve product and does not have an arginine dihydrolase system. Requires $\mathrm{Na}^{+}$for growth. Strictly aerobic. Chemo-organotroph. Cytochrome oxidase-, catalaseand alkaline phosphatase-positive. Does not decompose agar, starch, alginate, gelatin and chitinase. Phylogenetically is a member of the 'FlavobacteriumBacteroides' phylum. Contains one species, Arenibacter latericius, the type strain of which is KMM $426^{\mathrm{T}}$.

\section{Description of Arenibacter latericius gen. nov., sp. nov.}

Arenibacter latericius (la.te.ri'ci.us. L. adj. latericius of brick, here pertaining to the dark orange pigmentation).

Description as for the genus. In addition, colonies are circular, low convex, shiny with entire edges on solid media containing high nutrient components. Colonies are dark orange in colour because of non-diffusible carotenoid pigments. Flexirubin pigments are absent. No growth is detected at 4 and $42{ }^{\circ} \mathrm{C}$. Alkalitolerant. Does not hydrolyse gelatin or casein. Produces $\alpha-N$ acetylgalactosaminidase. Utilizes $\alpha$-D-glucose, L-glutamic acid, L-ornithine, uridine, glycerol, DL- $\alpha$-glycerol phosphate, glucose 1-phosphate and glucose 6-phosphate, according to the BIOLOG system. Dextrin, $N$-acetyl-D-galactosamine, $\quad N$-acetyl-D-glucosamine, cellobiose, $\mathrm{D}$-fructose, $\alpha$-lactose, $\alpha$-D-lactose lactulose, glycogen, maltose, D-mannitol, D-mannose, Dmellibiose, $\beta$-methyl-D-glucoside, D-raffinose, sucrose, D-trehalose, DL-lactic acid, turanose, succinamic acid, glucuronamide, alaninamide, L-alanine, L-alanylglycine, L-asparagine, L-aspartic acid, glycyl-L-aspartic acid, glycyl-L-glutamic acid, L-proline, D-serine, Lserine and L-threonine are weakly utilized. Susceptible to erythromycin, ampicillin, cephaloridin and lincomycin. Not susceptible to kanamycin, benzylpenicillin, oxacillin, neomycin, streptomycin, gentamicin and polymyxin B. The major polar lipid is phosphatidylethanolamine. Sphingophospholipids are absent. The predominant cellular fatty acids are odd-numbered, iso-branched (about $70 \%$ ) : 15:0, i15:0, a15:0, i15:1, $\mathrm{i} 17: 0 ; 16: 0,16: 1(\mathrm{n}-7), 18: 0,18: 1(\mathrm{n}-7)$ in minor quantities. The $\mathrm{G}+\mathrm{C}$ content of the DNA ranges from 37 to $38 \mathrm{~mol} \%$. Type strain is KMM $426^{\mathrm{T}}$ (VKM B $\left.2137 \mathrm{D}^{\mathrm{T}}=\mathrm{LMG} 19694^{\mathrm{T}}=\mathrm{CIP} 106861^{\mathrm{T}}\right)$, deposited in the Collection of Marine Micro-organisms (KMM) of the Pacific Institute of Bioorganic Chemistry, Vladivostok, the All-Russian Collection of Microorganisms, Moscow, Russia, and the Culture Collection of the Laboratory of Microbiology, University of Gent, Belgium. Isolated from the marine environment (sandy sediments, holothurian, brown alga).

\section{ACKNOWLEDGEMENTS}

Expert assistance in electron microscopy provided by $\mathrm{T}$. Maugel is greatly appreciated. This study was supported by a short-term UNESCO Fellowship, funds from the Russian Foundation for Basic Research, Grant No. 96-04-49058 and a grant from the State Committee for Science and Technologies of the Russian Federation, Grant No. 96-0319/97-03-19.

\section{REFERENCES}

Bakunina, I. Yu., Ivanova, E. P., Nedashkovskaya, O. I., Gorshkova, N. M., Elyakova, L. A. \& Mikhailov, V. V. (1996). Search for $\alpha$-galactosidase producers among marine bacteria of the genus Alteromonas. Prikl Biokh Mikrobiol 32, 624-628 (in Russian).

Bernardet, J.-F., Segers, P., Vancanneyt, M., Berthe, F., Kersters, K. \& Vandamme, P. (1996). Cutting a Gordian knot: emended classification and description of the genus Flavobacterium, emended description of the family Flavobacteriaceae, and proposal of Flavobacterium hydatis nom. nov. (Basonym, Cytophaga aquatilis Strohl and Tait 1978). Int J Syst Bacteriol 46, 128-148.

Bligh, E. G. \& Dyer, W. J. (1953). A rapid method of lipid extraction and purification. Can J Biochem Physiol 7, 911-915.

Botha, W. C., Jooste, P. J. \& Britz, T. J. (1989). The taxonomic relationship of certain environment flavobacteria to the genus Weeksella. J Appl Bacteriol 67, 551-559.

Bowman, J.P., McCammon, S. A., Brown, J., Nichols, P. D. \& McMeekin, T. A. (1997a). Psychroserpens burtonensis gen. nov., sp. nov. and Gelidibacter algens gen. nov., sp. nov.: psychrophilic bacteria from Antarctic lacustrien and sea ice habitats. Int J Syst Bacteriol 47, 670-677.

Bowman, J. P., McCammon, S. A., Brown, M. V., Nichols, P. D. \& McMeekin, T. A. (1997b). Diversity and association of psychrophilic bacteria in Antarctic sea ice. Appl Environ Microbiol 63, 3068-3078.

Bowman, J. P., McCammon, S., Lewis, T., Skerratt, J. H., Brown, J. L., Nichols, D. S. \& McMeekin, T. A. (1998). Psychroflexus torquis gen. nov., sp. nov., a psychrophilic species from Antarctic sea ice, and reclassification of Flavobacterium gondwanense (Dobson et al., 1993) as Psychroflexus gondwanense gen. nov., comb. nov. Microbiology 144, 1601-1609.

Chun, J. \& Goodfellow, M. (1995). A phylogenetic analysis of the genus Nocardia with $16 \mathrm{~S}$ rRNA gene sequences. Int $J$ Syst Bacteriol 45, 240-245.

De Ley, J., Cattoir, H. \& Reynaerts, A. (1970). The quantitative measurement of DNA hybridization from renaturation rates. Eur J Biochem 12, 133-142.

Fautz, E. \& Reichenbach, H. (1980). A simple test for flexirubintype pigments. FEMS Microbiol Lett 8, 87-91.

Felsenstein, J. (1985). Confidence limits on phylogenies: an approach using the bootstrap. Evolution 39, 783-791.

Felsenstein, J. (1993). PHYLIP (Phylogeny Inference Package) version 3.5.1. Seattle: Department of Genetics, University of Washington.

Fitch, W. M. (1972). Toward defining the course of evolution: minimum change for a specific tree topology. Syst Zool 20, 406-416.

Fitch, W. M. \& Margoliash, E. (1967). Construction of phylogenetic trees. Science 155, 279-284.

Gherna, R. \& Woese, C. R. (1992). A partial phylogenetic analysis of the 'flavobacter-bacteroides' phylum: a basis for taxonomic restructuring. Syst Appl Microbiol 15, 513-521.

Gosink, J. J., Woese, C. R. \& Staley, J. T. (1998). Polaribacter gen. nov., with three new species, $P$. irgensii sp. nov., $P$. franzmannii 
sp. nov. and P. filamentus sp. nov., gas vacuolate polar marine bacteria of the Cytophaga-Flavobacterium-Bacteroides group and reclassification of 'Flectobacillus glomeratus' as Polaribacter glomeratus comb. nov. Int J Syst Bacteriol 48, 223-235.

Holmes, B. (1993). Recent developments in Flavobacterium taxonomy. In Advances in the Taxonomy and Significance of Flavobacterium, Cytophaga and Related Bacteria, pp. 6-15. Edited by P. J. Jooste. Bloemfontein, South Africa: University of the Orange Free State Press.

Holmes, B., Owen, R. J. \& McMeekin, T. A. (1984). Genus Flavobacterium Harrison, Breed, Hammer and Huntoon. In Bergey's Manual of Systematic Bacteriology, pp. 353-361. Edited by N. R. Krieg \& J. G. Holt. Baltimore: Williams \& Wilkins.

Ivanova, E. P., Kiprianova, E. A., Mikhailov, V. V., Levanova, F. G., Garagulya, A. G., Gorshkova, N. M., Yumoto, N. \& Yoshikawa, S. (1996). Characterization and identification of marine Alteromonas nigrifaciens strains and emendation of the description. Int J Syst Bacteriol 46, 223-228.

Ivanova, E. P., Kiprianova, E. A., Mikhailov, V. V., Levanova, G. F., Garagulya, A. D., Gorshkova, N. M., Vysotskii, M. V., Frolova, G. M., Nicolau, D. V., Yumoto, Y. \& Yoshikawa, S. (1998). Phenotypic diversity of Pseudoalteromonas citrea from different marine habitats and emendation of the description. Int J Syst Bacteriol 48, 247-256.

Johansen, J. E., Nielson, P. \& Sjøholm, C. (1999). Description of Cellulophaga baltica gen. nov., sp. nov. and Cellulophaga fucicola gen. nov., sp. nov. and reclassification of [Cytophaga] lytica to Cellulophaga lytica gen. nov., comb. nov. Int J Syst Bacteriol 49, 1231-1240.

Jukes, T. H. \& Cantor, C. R. (1969). Evolution of protein molecules. In Mammalian Protein Metabolism, pp. 21-132. Edited by H. N. Munro. New York: Academic Press.

McGuire, A. J., Franzmann, P. D. \& McMeekin, T. A. (1987). Flectobacillus glomeratus sp. nov., a curved, nonmotile, pigmented bacterium isolated from antarctic marine environment. Syst Appl Microbiol 9, 265-272.

McMeekin, T. A., Patterson, J. T. \& Murray, J. G. (1971). An initial approach to the taxonomy of some gram-negative yellow pigmented rods. J Appl Bacteriol 34, 699-716.

Marmur, J. (1961). A procedure for the isolation of deoxyribonucleic acid from microorganisms. J Mol Biol 3, 208-218.

Marmur, J. \& Doty, P. (1962). Determination of the base composition of deoxyribonucleic acid from its thermal denaturation temperature. J Mol Biol 5, 109-118.

Mudarris, M., Austin, B., Segers, P., Vancanneyt, M., Hoste, B. \& Bernardet, J. F. (1994). Flavobacterium scophthalmum sp. nov., a pathogen of turbot (Scophthalmus maximus L.). Int J Syst Bacteriol 44, 447-453.

Naganuma, T., Coury, D. A., Polne-Fuller, M. \& Gibor, A. (1993). Characterization of agarolytic Microscilla isolates and their extracellular agarases. Syst Appl Microbiol 16, 183-190.

Nakagawa, Y. \& Yamasato, K. (1996). Emendation of the genus Cytophaga and transfer of Cytophaga agarovorans and Cytophaga salmonicolor to Marinilabilia gen. nov.: phylogenetic analysis of the Flavobacterium-Cytophaga complex. Int J Syst Bacteriol 46, 599-603.

Nakagawa, Y., Hamana, K., Sakane, T. \& Yamasato, K. (1997). Reclassification of Cytophaga aprica (Lewin 1969) Reichenbach 1989 in Flammeovirga gen. nov. as Flammeovirga aprica comb. nov. and of Cytophaga diffluens (ex Stanier 1940; emend. Lewin 1969) Reichenbach 1989 in Persicobacter gen. nov. as Persicobacter diffluens comb. nov. Int J Syst Bacteriol 47, 220-223.

Ruger, H.-J. \& Krambeck, H.-J. (1994). Evaluation of the BIOLOG substrate metabolism system for classification of marine bacteria. Syst Appl Microbiol 17, 281-288.

Saitou, N. \& Nei, M. (1987). The neighbor-joining method: a new method for reconstructing phylogenetic trees. Mol Biol Evol 4, 406-425.

Segers, P., Vandamme, P., Steyn, P. L., Mannheim, W., Willekens, H., Bauwens, M., De Ley, J. \& Kersters, K. (1993). Phylogenetic studies of Flavobacterium and related organisms by DNArRNA hybridization. In Advances in the Taxonomy and Significance of Flavobacterium, Cytophaga and Related Bacteria, pp. 129-136. Edited by P. J. Jooste. Bloemfontein, South Africa: University of the Orange Free State Press.

Smibert, R. M. \& Krieg, N. R. (1994). Phenotypic characterization. In Methods for General and Molecular Bacteriology, pp. 607-654. Edited by P. Gerhardt. Washington, DC: American Society for Microbiology.

Svetashev, V. I., Vysotskii, M. V., Ivanova, E. P. \& Mikhailov, V. V. (1995). Cellular fatty acid of Alteromonas species. Syst Appl Microbiol 18, 37-43.

Vandamme, P., Bernardet, J.-F., Segers, P., Kersters, K. \& Holmes, B. (1994). New perspective in the classification of the flavobacteria: description of Chryseobacterium gen. nov., Bergeyella gen. nov., and Empedobacter nom. rev. Int J Syst Bacteriol 44, 827-831.

Vaskovsky, V. E., Kostetsky, E. Y. \& Vasendin, I. M. (1975). A universal reagent for phospholipid analysis. J Chromatogr 114, 129-141.

Wayne, L. G., Brenner, D. J., Colwell, R. R. \& 9 other authors (1987). International Committee on Systematic Bacteriology. Report of the ad hoc committee on reconciliation of approaches to bacterial systematics. Int J Syst Bacteriol 37, 463-464. 